\title{
A NEGYEDIK IPARI FORRADALOM GAZDASÁGI ÉS MENEDZSMENTHATÁSAI
}

$\mathrm{A}$ z elmúlt néhány évben vállalati és kutatói körökben egyaránt elterjedt az a nézet, hogy egy új ipari forradalom vette kezdetét a világban. A technológiai alapokon nyugvó negyedik ipari forradalom nemcsak a társadalom, de a vállalatok, sőt egész ágazatok müködését alakítja át gyökeresen, elég csak példaként a precíziós mezőgazdaságra, a fintech vállalatokra, a platform alapon müködő cégekre (pl. Facebook, Uber, AirBnB) gondolni. A forradalom a vállalatok funkcionális területeinek müködését is új alapokra helyezi. E tematikus szám célja a technológiai változások menedzsmentre, vállalati müködésre, teljesítményre gyakorolt hatásainak számbavétele, elsősorban empirikus megközelítésben.

Az empirikus megközelítés azért is fontos, mert számos koncepcióval, kategorizálással, kormányzati anyaggal lehet találkozni, de sokkal kevesebb a tudományos alapokon készült, tényeken alapuló kutatás. Ezért hajlamosak lehetünk arra, hogy annak a néhány vállalatnak a példája alapján vonjunk le következtetéseket, amelyek a digitalizáció és a legújabb technológiák alkalmazása terén élen járnak.

A Vezetéstudomány folyóirat hasábjain már korábban is jelentek meg szép számmal az Ipar 4.0, tágabban a digitalizáció témájában empirikus cikkek (Csontos \& Szabó, 2018; Horváth, Móricz \& Szabó, 2018; Agárdi, 2018; Nagy, 2019; Csedő, Zavarkó \& Sára, 2019; Demeter, Losonci, Nagy \& Horváth, 2019; Demeter, Losonci, Szász \& Rácz, 2020; Rekettye, 2020; Demeter \& Losonci, 2020). Mindazonáltal a Vezetéstudomány szerkesztősége úgy gondolta, hogy célszerü egy tematikus szám segítségével tovább fókuszálnunk a figyelmet a negyedik ipari forradalom okozta kihívásokra.

\section{A digitalizáció, a negyedik ipari forradalom és az Ipar 4.0 kapcsolata}

Érdemes körüljárni röviden a digitalizáció, a negyedik ipari forradalom és az Ipar 4.0 kapcsolatát, már csak azért is, mert a hármat sokszor egyszerű szinonimaként kezeljük (Demeter \& Losonci, 2020). Pedig van köztük különbség. Hiszen a digitalizáció valójában a harmadik ipari forradalom terméke, ami a számítógép feltalálásával vette kezdetét, terjed és teljesedik ki még ma is a világban. Valójában a körülöttünk lévő fizikai világ lefordítását jelenti a számítógép nyelvére. A szkennelés, a digitális fényképezés és videókészítés, az e-kereskedelem, mind ennek a digitális forradalomnak a termékei.
A negyedik ipari forradalmat jellemző technológiák digitálisak, azaz amikor digitalizációról beszélünk, akkor abba ezek is beletartoznak. Abban egyébként koránt sincs megegyezés a szakirodalomban, hogy mely technológiák tartoznak ebbe a körbe, de a Big Data elemzés, a felhőalapú számítástechnika, a dolgok internete, a 3D nyomtatás és az intelligens robotok mindegyikben benne vannak. E technológiák sajátossága, hogy a valós és a virtuális világ nem választható el egymástól, folyamatosan egyikből a másikba mennek a jelek. A negyedik ipari forradalom alapegysége a kiberfizikai rendszer (cyber-physical system, CPS), ami hálózatba kapcsolt szenzorok és aktuátorok segítségével az oda-visszafordítást végzi. A negyedik ipari forradalom következtében okos termékek és szolgáltatások, okos gyárak és ezekre épülő új üzleti modellek (pl. platformvállalatok) jönnek létre, amelyek teljesen átalakítják nemcsak a gazdaság, hanem a társadalom müködését is. Elég, ha csak az X, Y, Z, sőt ma már Alfa generációk jellemzőire, az alapjövedelem körüli vitákra, vagy munkaerőpiaci hatásaira gondolunk.

Az Ipar 4.0 a negyedik ipari forradalom részhalmaza, ami a forradalom gazdasági vetületeire, elsősorban a termelővállalatokra fókuszál. Az Ipar 4.0 tehát a negyedik ipari forradalom technológiáit használja, amelyek a digitalizációra építenek, de a digitalizáción összekapcsoltságuk és CPS alapjaik révén többek a puszta digitalizációnál.

\section{A tematikus számban megjelenő cikkekről}

Tekintve, hogy az Ipar 4.0 hazánkban még gyerekcipőben jár (Losonci, Takács \& Demeter, 2019), ezért e számban is inkább a digitalizációval, esetleg szigetszerü Ipar 4.0 megoldások elemzésével találkozhatunk, mint teljes körü okos gyárakról szóló írásokkal.

A tematikus szám - empirikus alapjait tekintve - rendkívül sokszínű. Olvashatunk benne az autóipar és az élelmiszeripar digitalizációval kapcsolatos kihívásairól, de a termelőkön kívül találkozhatunk a logisztikai szolgáltatások, a kiskereskedelem, vagy az üzleti szolgáltatóközpontok sajátosságaival. Belepillanthatunk a kisvállalkozások helyzetébe, a munkavállalók gondolkodásába és láthatjuk, miként biztosítják az informatikai szolgáltatók a fejlődéshez szükséges technológiákat.

A szám hét cikkéből öt egy kutatás berkein belül készült, amely az Ipar 4.0 ellátási láncokra gyakorolt hatásának vizsgálatával foglalkozott. Az ellátási láncot a kutatás néhány kulcspozíción keresztül - gyártó, logisztikai szol- 
gáltató, kiskereskedő, üzleti szolgáltató, informatikai szállító - ragadta meg részletes esettanulmányok segítségével. Bár az empirikus alapok hasonlóak, a cikkek egészen eltérő témákat helyeznek a középpontba. Először ezek az egy kutatáshoz tartozó cikkek olvashatóak.

Itt érdemes megjegyezni, hogy a kutatás keretében készült Demeter et al. (2020) cikke, ami az autóipari fejlesztésekkel foglalkozik, csak terjedelmi okokból került át másik lapszámba. Ugyanígy járt Rekettye (2020) cikke is, ami a digitalizációnak az árazási megoldásokra gyakorolt hatását elemzi.

Kezdve tehát a tematikus szám bemutatását, a gyártó szemszögével indulunk. Nagy Judit, Jámbor Zsófia és Freund Anna cikke „Az Ipar 4.0 és a digitalizáció legjobb gyakorlatai a hazai élelmiszergazdaságban” címmel a húsipar, a tejipar és a tésztagyártás négy szereplőjének digitalizációs törekvéseit vizsgálja egy erre a célra kialakított keretrendszerben összevetve őket. A részletesen bemutatott vállalati példák jól érzékeltetik az új technológiák lehetőségeit és kihívásait. A szerzők rámutatnak arra, hogy bár a fejlesztések főként a termelési folyamatok modernizálására irányulnak, hatásaik azokon jóval túlnyúlnak.

A logisztikai szolgáltatókról ír Diófási-Kovács Orsolya „Logisztika 4.0 - Digitalizációs projektek hatása a fenntarthatósági teljesítményre" címmel. Mivel a logisztikának jelentős hatása van a környezeti terhelésre, ezért nem véletlen, hogy a szerző a digitalizációs törekvések fenntarthatóságra gyakorolt hatását helyezi vizsgálatának középpontjába, amelyet négy logisztikai szolgáltatónál végzett el. Az eredmények alapján a fenntarthatóság három fö pillére (gazdasági, környezeti, társadalmi) közül leginkább a gazdasági pillér javul a digitalizáció hatására. A környezeti és a társadalmi pillérben is vannak átrendeződések, de ezeken a területeken kevésbé egyértelmü a változások iránya.

Matyusz Zsolt és Pistrui Bence „Digitalizációs projektek a magyar kiskereskedelmi szektorban” címen futó tanulmányukban egy divatcikkek és egy sportcikkek forgalmazásával foglalkozó kiskereskedő fejlesztéseibe nyújt bepillantást. Elemzéseik alapján - bár a két cég teljesen eltérő piacszerkezettel, piaci pozícióval és szervezeti kultúrával rendelkezik - a digitalizáció mindkét vállalatnál elsőként a back-end vonalon indult el (a fogyasztókat kiszolgáló személyzet megtámogatásával), de a front-end (fogyasztókat közvetlenül érintő) megoldások is fokozatosan teret nyernek.

Az ellátási láncok szempontjából egyre fontosabb szerepet játszanak az üzleti szolgáltató központok, amelyek a hatékonyság növelését és a költségek csökkentését teszik lehetővé úgy, hogy közben a minőség is javul. Marciniak Róbert, Móricz Péter és Baksa Máté „Lépések a kognitív automatizáció felé" című cikkükben egy ilyen szolgáltatóközpontot helyeznek vizsgálódásuk fókuszába. A digitális átállást befolyásoló legfontosabb tényezőként a célok és keretek megfelelő kijelölését, a szervezeti kultúrát, a digitalizációhoz szükséges szerepek és képességek kialakítását, illetve a technológia kiválasztását határozzák meg a szerzők.
Logikai szempontból akár kezdhettük volna a cikkek sorát Ternai Katalin cikkével is, ami „Az Ipar $4.0 \mathrm{az}$ ERP-szállítók perspektívájából" címet viseli. Hiszen az ERP-szállítók adják meg azokat az alapokat, amelyekre az Ipar 4.0 technológiák épülnek. A cikk részletesen bemutatja az ERP-szállítók által nyújtott lehetőségeket és azt a kapcsolódó ökoszisztémát, ami segít abban, hogy ezek a megoldások kisebb és nagyobb vállalatokhoz, szükség esetén testre szabva - egyaránt eljussanak.

A tematikus szám további két cikke más perspektívából vizsgálja a technológiai megújulás hatását. Keszey Tamara és Tóth Réka Zsuzsanna „Ipar 4.0 az autóiparban: A fehér és kékgalléros munkavállalók technológiaelfogadási aggályai" címmel a munkavállalói szemszöget használja. A szerzők rámutatnak arra, hogy nem elég a munkavállalókat képessé tenni az új technológiák használatára, foglalkozni kell a munkavállalói aggályokkal, így a robotizációtól és az elbocsátástól, vagy éppen az állandó megfigyeléstől való félelemmel.

A tematikus szám utolsó cikke a digitalizáció technológiai vállalkozásokra gyakorolt hatását elemzi, „Új technológiai cégek az Ipar 4.0 küszöbén - a magyar digitális vállalkozási ökoszisztéma szakértői értékelése" címmel Szerb László, Komlósi Éva és Páger Balázs tollából. A szakértői véleményekre épülő kutatás az ökoszisztéma három fö problémáját azonosítja: 1) az információkezelést és adatbiztonságot, 2) az induláshoz szükséges magas tőkeigényt és 3) a humán kapacitás korlátait.

Szerkesztőként szeretném megköszönni a közremüködők segítségét: elsősorban Kő Andreáét, aki a bírálati folyamatban segített, de minden szerzőnek, aki cikket benyújtott, és minden bírálónak, aki rászánta az időt, hogy a bírált cikket jobbá tegye. Remélem, az Olvasó hasznosnak fogja találni.

Demeter Krisztina

\section{Felhasznált irodalom}

Agárdi, I. (2018). A digitalizáció mint a kiskereskedelmi tevékenységet integráló tényező. Vezetéstudomány, 49(12), 50-57.

https://doi.org/10.14267/ VEZTUD.2018.12.06

Csedő, Z., Zavarkó, M., \& Sára, Z. (2019). Innováció-e a digitalizáció - A digitális transzformáció és az innovációmenedzsment tanulságai egy pénzügyi szolgáltatónál. Vezetéstudomány, 50(7-8), 88-101. https://doi.org/10.14267/VEZTUD.2019.07.08

Csontos, R. S., \& Szabó, Z. R. (2018). A versengés új színterei: platformok stratégiaimenedzsmentmegközelítésböl. Vezetéstudomány, 49(9), 57-69. https://doi.org/10.14267/VEZTUD.2018.09.05

Demeter, K., \& Losonci, D. (2020). Business and Technological perspectives of Industry $4.0-a$ framework for thinking with case illustration. Vezetéstudomány, 51(5), 2-14. https://doi.org/10.14267/ VEZTUD.2020.05.01

Demeter, K., Losonci, D., Nagy, J., \& Horváth, B. (2019). Tapasztalatok az Ipar 4.0-val - Egy esetalapú elemzés. Vezetéstudomány, 50(4), 11-23. https://doi.org/10.14267/ VEZTUD.2019.04.02 
Demeter, K., Losonci, D., Szász, L., \& Rácz, B.-G. (2020). Magyarországi gyártóegységek Ipar 4.0 gyakorlatának elemzése - technológia, stratégia, szervezet. Vezetéstudomány, 51(4), 2-14.

https://doi.org/10.14267/ VEZTUD.2020.04.01

Horváth, D., Móricz, P., \& Szabó, Z. R. (2018). Üzletimodellinnováció. Vezetéstudomány, 49(6), 2-12. https://doi.org/10.14267/VEZTUD.2018.06.01

Losonci, D., Takács, O., \& Demeter, K. (2019). Az ipar 4.0 hatásainak nyomában - a magyarországi jármüipar elemzése. Közgazdasági Szemle, 66(2), 185-218.

http://dx.doi.org/10.18414/Ksz.2019.2.185

Nagy, J. (2019). Az Ipar 4.0 fogalma és kritikus kérdései vállalati interjúk alapján. Vezetéstudomány, 50(1), 14-26. https://doi.org/10.14267/VEZTUD.2019.01.02

Rekettye, G. (2020). Az Ipar 4.0 hatása az árakra és a vállalati árképzés gyakorlatára. Vezetéstudomány, 51(4), 15-25.

https://doi.org/10.14267/VEZTUD.2020.04.02 